Books, videos, CD-ROMs and any other relevant items submitted for a review in the $B D J$ should be addressed to: Mike Grace, Editor, British Dental Journal, 64 Wimpole Street, London WI G 8YS.

\section{Local anaesthesia in dentistry}

\section{P. D. Robinson, T. Pitt Ford, \\ F. McDonald (ed) \\ Oxford: Wright - Butterworth \\ Heinemann, 2000 \\ price $\mathfrak{E} 13.99$, pp 104 \\ ISBN 0-7236-10630}

This book was inspired by its predecessor (of the same name) by Geoffrey Howe and Ivor Whitehead and was published as part of the General Practitioner Handbook series in the 1970s. This new book is devoted mainly to providing the reader with the core knowledge that underpins the practice of local anaesthesia. The first two chapters deal with physiological and pharmacological aspects of local anaesthesia and provide an excellent revision of the basic science that is relevant to the clinical subject. The main body of the text reviews instrument selection, techniques for infiltration and block anaesthesia, selection of patients, management of difficult cases and possible complications that may occur. The text is supplemented with tables, diagrams and figures which both enhance and facilitate the learning process. Aspects of anatomy that are covered are again, only those relevant to the clinical situation and the authors acknowledge that the reader will be very aware of more detailed texts (or perhaps lecture notes) that might be consulted should greater factual detail be needed. The final chapter discusses medico-legal implications with reference in particular, to three recent studies from the dental literature. Each chapter is

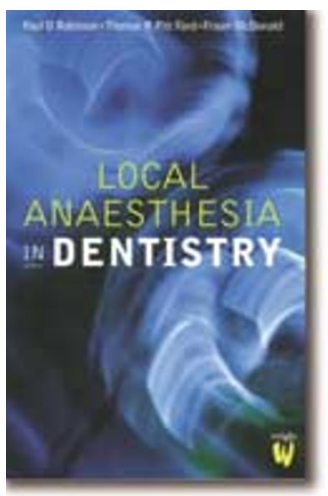

concluded with a short list of further upto-date articles and texts that may be consulted for additional information.

The textbook is written primarily for undergraduates who are about to embark upon clinical dentistry although the book will also be a more-than-useful reference for more senior students and graduates. It is affordable, easy to carry around in a tunic or coat and most certainly readable from cover-to-cover in a couple of hours. As such, it will help to ensure a rapid and relatively seamless transition from pre-clinical to clinical dentistry for those who choose to make the investment.

[BD] 852]

P. A. Heasman

\section{Development, function and evolution of teeth}

M. F. Teaford, M. Meredith Smith,

M. W. J. Ferguson

Cambridge University Press, 2000

price $\mathfrak{E} 65.00$, pp314

ISBN 0-521-5701 1-5

My first reaction on learning that this book was the product of a symposium held in 1994 was to wonder what the participants had been up to for the past 6 years. After reading the text however it became clear that the contributors had been hard at work both publishing new research and updating their chapters. The result is an excellent and authoritative text which is fascinating in places. In particular the editorial team is to be congratulated on producing a multi-authored book which combines material provided by molecular biologists, developmental biologists, functional morphologists, dental researchers and paleontologists in a cohesive and structured fashion. In the final chapter, Mark Teaford explains the philosophy behind this book with a quote from Schmidt-Kittler and Vogel's Constructional Morphology and Evolution, which says it all, 'We will never understand organisms without an integrative approach.' The strength of this unique book lies in its integrative approach.

The first four chapters deal with the genetic and biochemical basis of tooth initiation. There has been a huge expansion of knowledge in this area in the past 20 years. The major role of the enamel knot in specifying crown form is reviewed. Expression of homeobox and other genes important in tooth initiation are restricted to this longknown microscopic structure at certain

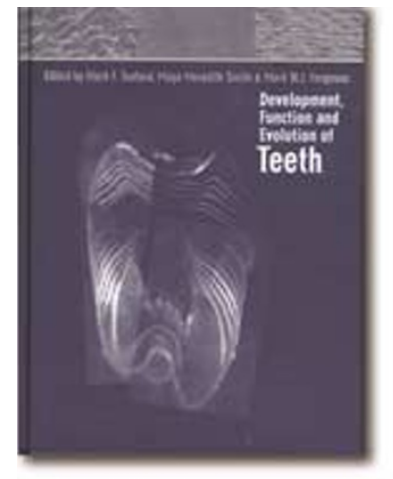

critical stages of crown development. Excellent accounts of the molecular basis of dental hard tissue formation are provided also. The next five chapters are devoted to the development and evolution of tooth tissues. These chapters provide a detailed and readable account of the earliest dental tissues in the fossil record and their subsequent evolution. Advances in knowledge relating to contemporary dental microstructure are integrated with findings in ancient tissues to give the reader better understanding of the evolution of structure. Subsequent chapters deal with the evolution of tooth shape and dentition and these are also excellent. The final section on macrostructure and function consists of less-related self-contained chapters. The highlight for me was the short chapter by A. Huysseune on developmental plasticity. Work on cichlid fishes has shown that tooth size and number may not be entirely genetically determined but may change with environmental factors such as diet. Demonstration of such adaptive variation in extant fishes is an important contribution to evolutionary theory.

Although the book is nicely produced, the only down side is that no colour illustrations are included. Also the artwork could be better and some figure legends are hard to follow, with occasional missing arrows and minor errors.

This book will be of interest to a wide range of scientists. Dentists who want to extend their understanding of the tissues on which our profession is founded will also find this book fascinating. It is aimed at the serious scientific reader; those who have not updated their knowledge of basic science since 2nd BDS may need to consult their dictionary of biology.

This book is certainly not a 'conference proceedings'. It is well edited and likely to become a standard reference on the subject of the biology of teeth for the next few years.

[BD] 849]

P. Sloan 